\title{
Bifunctional electrodes for unitised regenerative fuel cells
}

\author{
Sebastian Altmann ${ }^{\mathrm{a}}$, Till Kaz ${ }^{\mathrm{b}}$, Kaspar Andreas Friedrich ${ }^{\mathrm{a}, \mathrm{b}, *, 1}$ \\ a Institute of Thermodynamics and Thermal Engineering, University Stuttgart, Pfaffenwaldring 6, 70550 Stuttgart, Germany \\ b Institute of Technical Thermodynamics, German Aerospace Centre, Pfaffenwaldring 38-40, 70569 Stuttgart, Germany
}

\section{A R T I C L E I N F O}

\section{Article history:}

Received 20 October 2010

Received in revised form 14 January 2011

Accepted 21 January 2011

Available online 28 January 2011

\section{Keywords:}

Unitised regenerative fuel cell

Electrolysis

Electrode design

\begin{abstract}
A B S T R A C T
The effects of different configurations and compositions of platinum and iridium oxide electrodes for the oxygen reaction of unitised regenerative fuel cells (URFC) are reported. Bifunctional oxygen electrodes are important for URFC development because favourable properties for the fuel cell and the electrolysis modes must be combined into a single electrode. The bifunctional electrodes were studied under different combinations of catalyst mixtures, multilayer arrangements and segmented configurations with single catalyst areas. Distinct electrochemical behaviour was observed for both modes and can be explained on the basis of impedance spectroscopy. The mixture of both catalysts performs best for the present stage of electrode development. Also, the multilayer electrodes yielded good results with the potential for optimisation. The influence of ionic and electronic resistances on the relative performance is demonstrated. However, penalties due to cross currents in the heterogeneous electrodes were identified and explained by comparing the performance curves with electrodes composed of a single catalyst. Potential improvements for the different compositions are discussed.
\end{abstract}

(C) 2011 Elsevier Ltd. All rights reserved.

\section{Introduction}

Fuel cells offer attractive benefits as energy supply devices for different portable and mobile applications. In comparison to batteries, the energy density and the specific energy are higher, and extended operation times without external energy support can be realised. Mass and volume benefits can be achieved in advanced stack and system designs. However, one drawback of fuel cells for portable applications is the need for an external continuous supply of hydrogen and oxygen. While the latter can be acquired from the air, the use of fuel cells needs an infrastructure with $\mathrm{H}_{2}$ production facilities and refilling stations.By using a unitised regenerative fuel cell (URFC), a closed loop system can be achieved. URFCs can regenerate fuel (hydrogen) and oxidant (oxygen) by water electrolysis with an external energy supply, such as a photovoltaic cell or a wind turbine. This combination has the potential to be a near-zero emission energy supply system. In this respect, a URFC system is directly comparable to a secondary battery, especially in terms of user handling and the charging/discharging behaviour. The high specific energy and the increased energy density of a URFC are attractive for aerospace applications (i.e., satellites and high altitude aircrafts) and for energy storage in terrestrial regenerative systems [1-5].

\footnotetext{
* Corresponding author.

E-mail address: Andreas.Friedrich@dlr.de (K.A. Friedrich).

1 ISE member.
}

An ordinary pure hydrogen/air polymer electrolyte fuel cell uses Pt as the catalyst for the hydrogen electrode. The electrode for the oxygen reaction is more complex. Pt shows superior reactivity in fuel cells, but it simultaneously produces very high overpotentials in the electrolysis mode. In the literature [3,6-15], different alternative catalysts are proposed, primarily $\mathrm{Ir}, \mathrm{Ru}$, their oxides and combinations of them. To identify the best catalyst for oxygen evolution in combination with the DLR dry spraying technique, a screening study of commercially available catalyst powder materials was performed. $\mathrm{IrO}_{2}$ was found to perform best with superior long-term stability. Unfortunately, the activity of this material for oxygen reduction in the fuel cell mode is rather low. Hence, the use of two catalysts is inevitable.

In this work, various electrode designs with $\mathrm{Pt}$ and $\mathrm{IrO}_{2}$ catalysts were investigated. For the hydrogen electrode, platinum was used as the catalyst and the configuration was not changed during the experiment.

\section{Approach}

The three different options that are compared in the fuel cell (FC) and the electrolysis modes (EC) are illustrated in Fig. 1.

\subsection{Option 1 - mixture}

A simple mixture of both materials is the most common configuration in the literature $[3,7,9,15]$, and it is used as the reference design for this work. The advantage of this option is the 

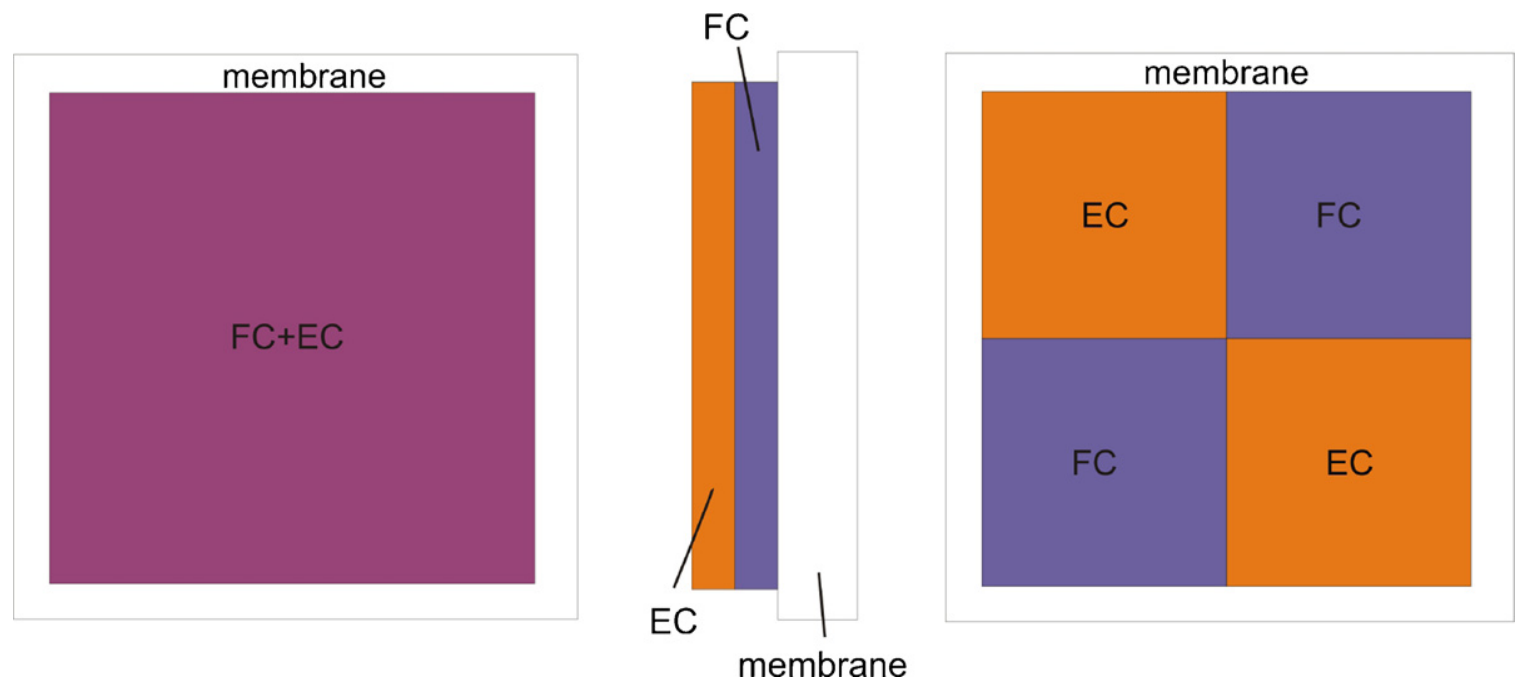

Fig. 1. Oxygen electrode configurations (left: Option 1 - mixture of both catalysts, middle: Option 2 - multilayer electrode, right: Option 3 - segmented electrode).

simple preparation of the membrane electrode assembly (MEA), which requires only one production step. However, the mixture of two different catalysts for separate chemical reactions involves compromises in structure and reactivity. Because there are no specific reaction areas, the properties of the gas diffusion layer (or backing; GDL) have to be a compromise between hydrophobic (fuel cell mode) and hydrophilic (electrolysis mode) properties.

\subsection{Option 2 - multilayered electrode}

As an alternative to the mixture, two electrode layers, one for the FC mode and another for the EC mode, are applied onto the membrane. During operation, specific electrodes for both working directions are available. The order of the layers can be varied with Pt in contact with either the electrolyte (Option 2_1) or the GDL (Option 2_2). In this multilayered electrode, the electrical and the ionic resistances are important properties. While the inner layer exhibits superior proton transfer to the membrane, the outer layer has better electronic conductivity to the bipolar plate. To obtain a better understanding of the behaviour of the electrodes, the Option 2 MEAs were equipped with different loadings of $\mathrm{IrO}_{2}$. With this approach, the number of catalyst particles and the thickness of the catalyst layer changes.

The use of multilayer electrodes offers fully active areas of the electrode for each mode, and good performance can be expected. However, the electrical and ionic contacts between the electrode, membrane and current collector can be a problem. Also, the transport of gases or water can be reduced because of small pores within the outer layer, and this may lead to diffusion limitation at specific current densities, which is well known in fuel cell development.

\subsection{Option 3 - segmented electrode}

In the third design, the active areas are split into separate zones for the fuel cell and the electrolysis reactions. Different configurations are possible, such as a few large areas (square design) or smaller sizes (design with stripes). As a further step, the segment geometry can be adapted to the flow field.

The segmented electrode allows the use of partially optimised gas diffusion media. The GDLs can be structured with an adapted level of hydrophobicity. In this configuration, pure catalysts that yield very good performance for specific operation modes are applied. However, by dividing the electrode into different parts, the active area is effectively reduced. Therefore, the current and performance of the entire cell are expected to decrease.

\section{Experimental}

All of the MEAs were manufactured by a dry spraying technique developed at DLR [16]. Platinum black (Pt) and iridium (IV) oxide $\left(\mathrm{IrO}_{2}\right)$ are used as the catalysts. To increase the proton conductivity of the electrodes $30 \mathrm{wt}$ \% Nafion is added. The membrane for all of the MEAs is Nafion ${ }^{\circledR} 1135$. The membranes were pretreated in $\mathrm{H}_{2} \mathrm{O}_{2}$ and $\mathrm{H}_{2} \mathrm{SO}_{4}$ before use. To fix the catalytic layer to the membrane at the end of the preparation, all of the MEAs were hot rolled at standard DLR conditions, which are a rolling temperature of $433 \mathrm{~K}$, a rotation speed of $0.6 \mathrm{~Hz}$ and contact pressure of $90 \mathrm{~kg}$.

Table 1 shows all of the MEAs that were used to compare the three options. All of the hydrogen electrodes with the exception of Option 1 had a lower loading of Pt on the hydrogen electrode as compared to the oxygen electrode because the oxygen electrode is expected to significantly influence the cell performance.

Table 1

Prepared membrane electrode assemblies.

\begin{tabular}{|c|c|c|c|c|c|}
\hline \multirow[t]{2}{*}{ Name } & \multicolumn{2}{|c|}{ Hydrogen } & \multicolumn{2}{|l|}{ Oxygen } & \multirow[t]{2}{*}{ Structure } \\
\hline & Catalyst & Loading $\left(\mathrm{mg} / \mathrm{cm}^{2}\right)$ & Catalyst & Loading $\left(\mathrm{mg} / \mathrm{cm}^{2}\right)$ & \\
\hline Option 1 & Pt black & 1.56 & $\mathrm{IrO}_{2}+\mathrm{Pt}(1: 1)$ & 1.61 & Mixed \\
\hline $\begin{array}{l}\text { Option 2_1 } \\
\text { Option 2_2 }\end{array}$ & $\begin{array}{l}\text { Pt black } \\
\text { Pt black }\end{array}$ & $\begin{array}{l}0.70 \\
0.70\end{array}$ & $\begin{array}{l}\mathrm{Pt} \text { and } \mathrm{IrO}_{2} \\
\mathrm{IrO}_{2} \text { and } \mathrm{Pt}\end{array}$ & $\begin{array}{l}0.93 / 0.78 \\
0.78 / 0.87\end{array}$ & $\begin{array}{l}\text { Multilayer (Pt inside) } \\
\text { Multilayer ( } \mathrm{IrO}_{2} \text { inside) }\end{array}$ \\
\hline $\begin{array}{l}\text { Option 3_11 } \\
\text { Option 3_12 } \\
\text { Option 3.2 }\end{array}$ & $\begin{array}{l}\text { Pt } \\
\text { black } \\
\text { Pt black }\end{array}$ & $\begin{array}{l}0.87 \\
0.87\end{array}$ & $\begin{array}{l}\mathrm{IrO}_{2} / \mathrm{Pt} \\
\mathrm{IrO}_{2} / \mathrm{Pt}\end{array}$ & $\begin{array}{l}0.73 / 0.73 \\
0.73 / 0.73\end{array}$ & $\begin{array}{l}\text { Segmented } \\
\text { (square) } \\
\text { Segmented (stripes) }\end{array}$ \\
\hline
\end{tabular}



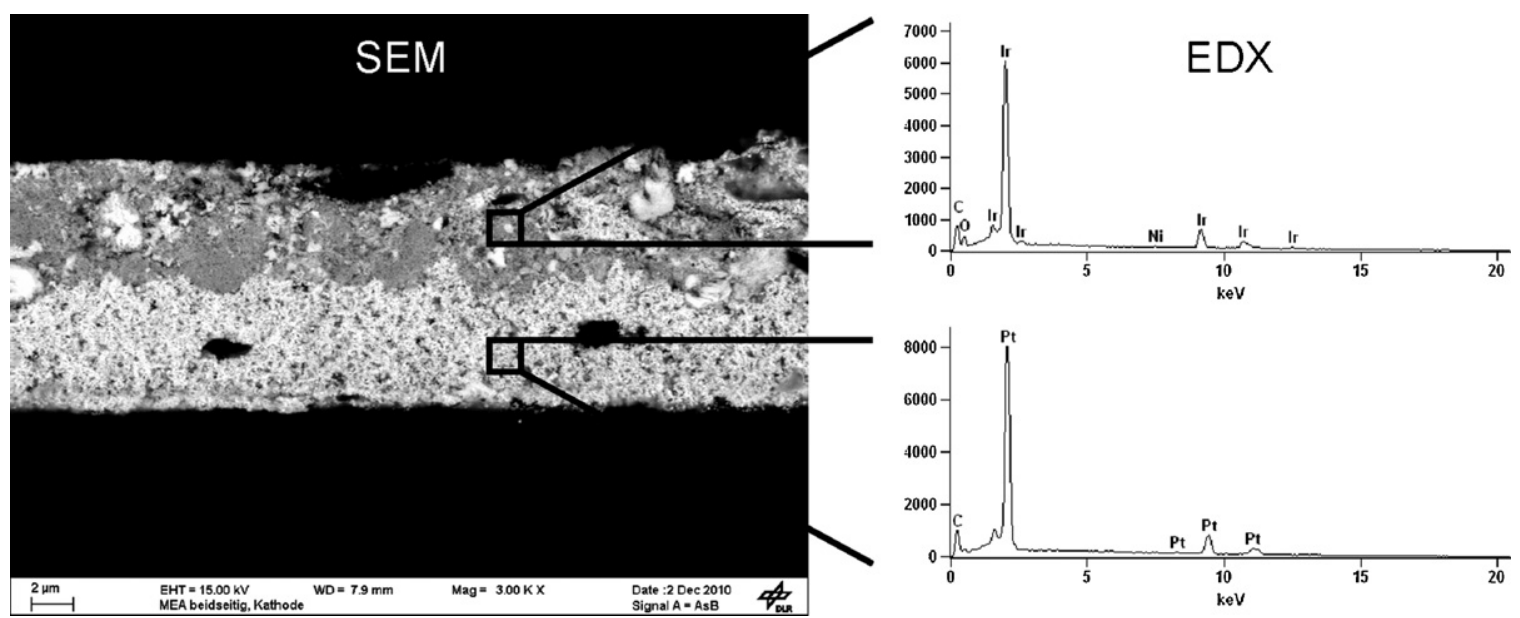

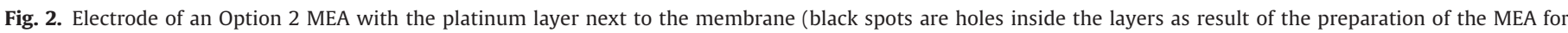
SEM/EDX).

The MEAs were tested in a single cell with Sigracet SGL 35 DC gas diffusion media (backing) and a parallel serpentine flow field. Hydrogen and oxygen were fed as reactant gases because of the reversibility of the system. The cell temperature in fuel cell mode was between 353 and $358 \mathrm{~K}$, and it was $368 \mathrm{~K}$ in electrolysis mode. The gas flow was $0.251 \mathrm{~min}^{-1}$ at the anode and $0.21 \mathrm{~min}^{-1}$ at the cathode. In fuel cell mode, both gases were fully humidified. The polarisation curves $E(j)$ were performed potentiostatically in fuel cell mode (beginning at the open cell output potential difference) and galvanostatically in electrolysis mode (starting at $0 \mathrm{~A}$ ). Each step was maintained for $2 \mathrm{~min}$.

An IM6/PP240 (Zahner GmbH) was used for the electrochemical impedance spectroscopic (EIS) measurements between $30 \mathrm{mHz}$ and $100 \mathrm{kHz}$. For the polarisation curve determination, an electronic load EL 1000 (Zentro GmbH) was used.

All MEAs (except Option 3_11) were tested in the same way. The electrolysis mode, polarisation curves and EIS measurements were recorded for $6-8 \mathrm{~h}$. The cell was then switched to the fuel cell mode, and the analyses were repeated. Option 3_11 was evaluated in the opposite way. For this option, the tests were started in fuel cell mode and then switched to electrolysis mode.

\section{Results and discussion}

Variations in the cell design for Option 2 and Option 3 and their behaviour are discussed in the following section. Option 1 was chosen as the reference design case, and the variations are not discussed here.

\subsection{Option 2}

For investigations on multilayer MEAs, the arrangement of layers in the electrode is of high interest. Fig. 2 shows one of the configurations for a multilayer MEA. Here the platinum electrode for the fuel cell mode is next to the membrane, and $\mathrm{IrO}_{2}$ is layered on top. This configuration is named Option 2_1. In the other configurations, called Option 2_2, the Pt layer is located on the exterior, and the $\mathrm{IrO}_{2}$ layer is next to the membrane. By using scanning electron microscopy (SEM) and energy-dispersive X-ray spectroscopy (EDX), the configuration of the electrode is determined by identifying the two materials (Fig. 2). In addition, the thickness of both electrodes is checked. In Fig. 2, the layers are homogeneous. Images at other positions on this MEA showed similar results. At a few locations, the thickness of the layers varied significantly due to either (1) the preparation by dry spraying and hot rolling or (2) the prepa-

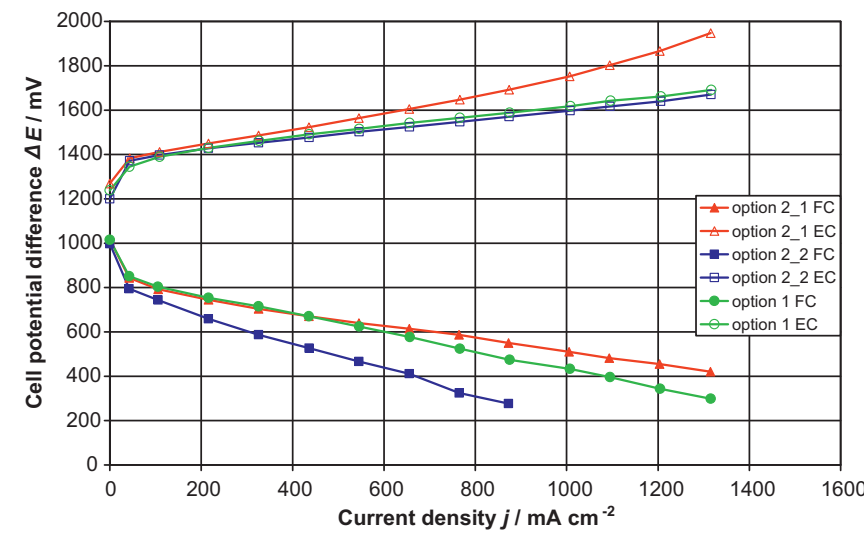

Fig. 3. $E(j)$ curves of Option 2 and Option 1 membrane electrode assemblies. (fuel cell mode: cell temperature $358 \mathrm{~K}$, ambient pressure, gases fully humidified, hydrogen flow $0.41 \mathrm{~min}^{-1}$, oxygen flow $0.41 \mathrm{~min}^{-1}$; electrolysis mode: cell temperature $368 \mathrm{~K}$, ambient pressure; no flows).

ration of the cross-sections (the samples are imbedded in resin and then cut). However, the effects of those fluctuations $(10 \mu \mathrm{m} \pm 1 \mu \mathrm{m}$ for each electrode) are about $10 \%$. The black spots inside the electrodes are the results of holes due to the preparation of the MEA for the SEM and EDX studies and are not related to the dry spraying technique.

The polarisation curves for all of the Option 2 MEAs are shown in Fig. 3. For comparison, the $E(j)$ curves of the Option 1 MEAs are included. The performance of the multilayered MEA is linked to the sequence of the catalysts layers in the electrode. If the Pt layer is inside and therefore in direct contact with the membrane (Option $2 \_1$ ), superior results in the fuel cell mode are achieved, and the polarisation curve is nearly the same as the Option 1 MEA. However, the performance in electrolysis mode for the same configuration shows higher overpotentials than the Option 1 MEA. Comparing this result with the second Option 2 MEA having the $\mathrm{IrO}_{2}$ layer next to membrane (Option 2_2), the results are interchanged. Superior performance is achieved in electrolysis mode, and lower performance is found in fuel cell mode.

To understand the behaviour of the Option 2 MEAs, EIS was used to obtain detailed information about the characteristics of each component (i.e., the performance of the anode, cathode and membrane). An equivalent circuit for the complete polymer electrolyte fuel cell (PEFC) in Fig. 5 was used for the simulation of the measured impedance spectra of the PEFC. In addition to the 

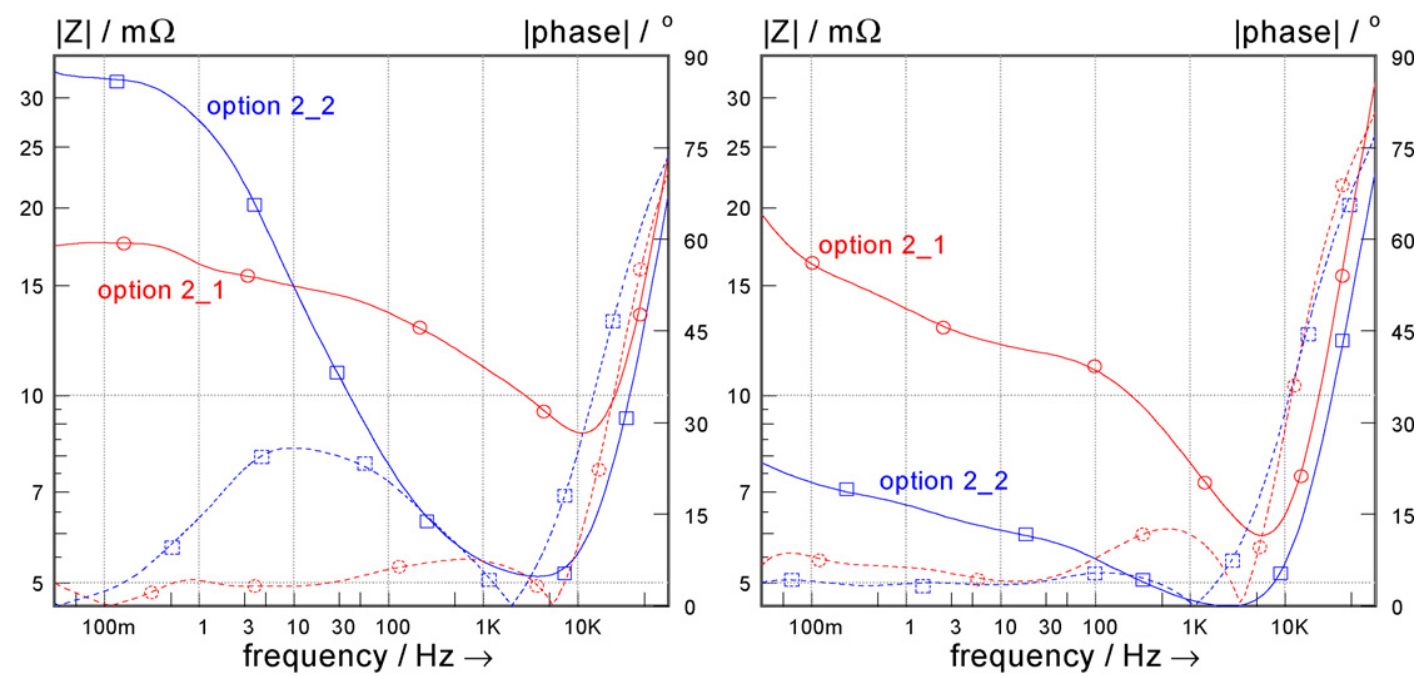

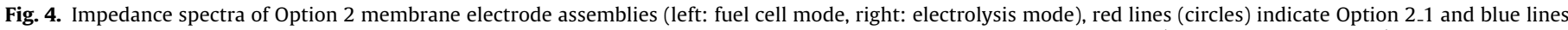

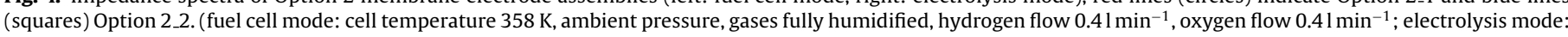
cell temperature $368 \mathrm{~K}$, ambient pressure). (For interpretation of the references to color in this figure legend, the reader is referred to the web version of the article.)
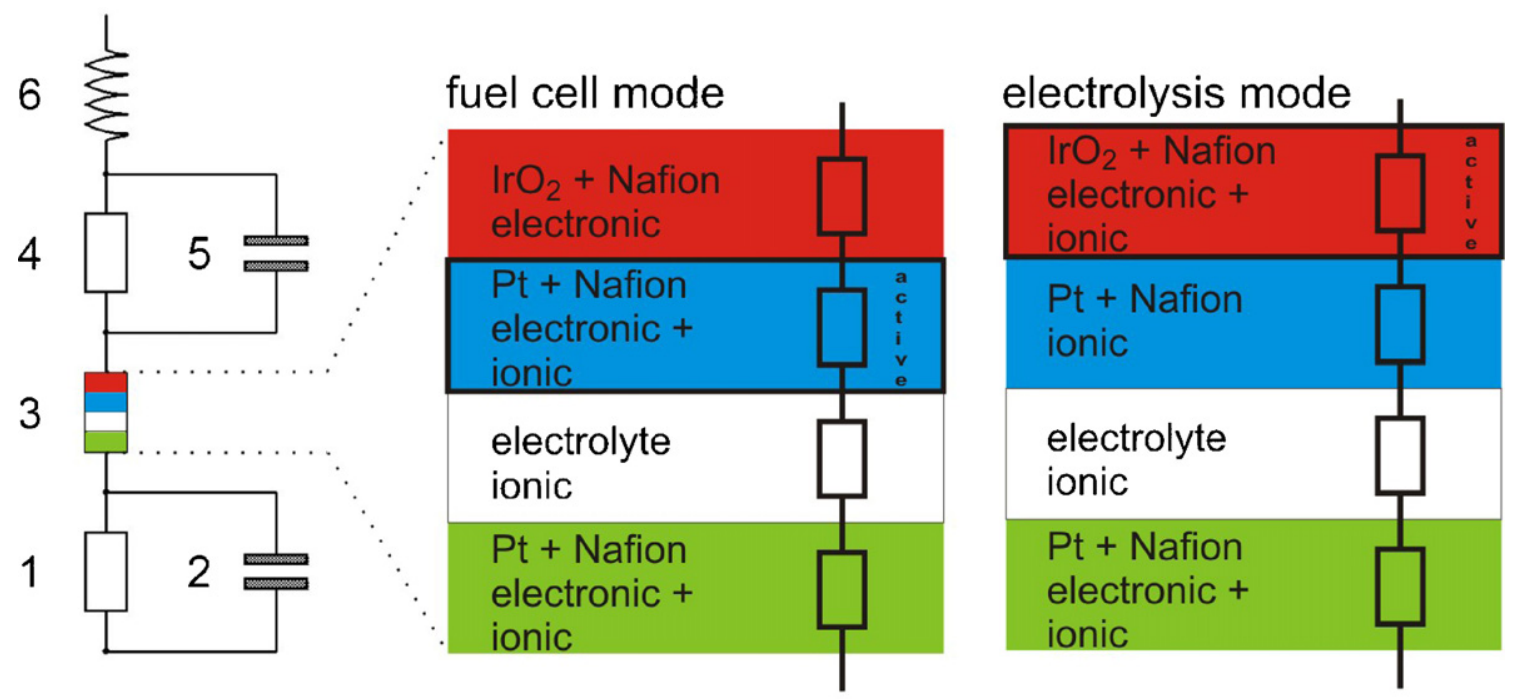

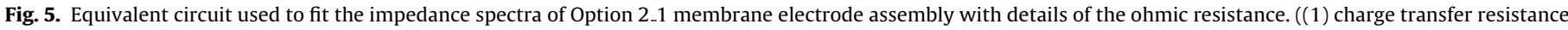

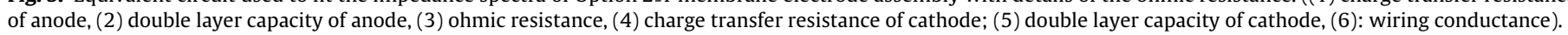

series resistance (contact plus membrane resistance $R_{\mathrm{el}}$ ), the equivalent circuit (Fig. 5) contains two parallel RC terms, with two time constants, which are potential dependent. In the simulation of the measured impedance spectra, the ideal capacitance $(C)$ was replaced by constant phase element (CPE) due to the porous structure of the electrodes. The inductances of the electrical circuit (mainly from the cables) are considered in element 6 . The ohmic resistance (element 3 ) depends strongly on the electrode config- uration because the multilayer structures investigated here give predominantly ionic or electronic conductivity contributions.

Fig. 4 shows the impedance spectra of the fuel cell (left side) and electrolysis (right side) modes. As expected, the impedance of the Option 2_2 MEA is much lower in electrolysis mode than the Option 2_1 MEA over the entire frequency range. The superior contact of the active $\mathrm{IrO}_{2}$ layer to the membrane yields increased proton conductivity and a reduced resistance. The fit to this equivalent circuit

Table 2

Fit of impedance spectra of MEA option 2 to equivalent circuit in Fig. 5.

\begin{tabular}{|c|c|c|c|c|c|c|c|c|c|}
\hline \multirow{2}{*}{$\begin{array}{l}\text { Element } \\
\text { MEA }\end{array}$} & \multirow{2}{*}{$\begin{array}{l}1 \\
\mathrm{~m} \Omega\end{array}$} & \multicolumn{2}{|l|}{2} & \multirow{2}{*}{$\begin{array}{l}3 \\
\mathrm{~m} \Omega\end{array}$} & \multirow{2}{*}{$\begin{array}{l}4 \\
\mathrm{~m} \Omega\end{array}$} & \multicolumn{2}{|l|}{5} & \multirow{2}{*}{$\begin{array}{l}6 \\
\mathrm{nH}\end{array}$} & \multirow{2}{*}{$\begin{array}{l}\text { Error } \\
\%\end{array}$} \\
\hline & & $\mathrm{mF}$ & CPE exp. & & & $\mathrm{mF}$ & CPE exp. & & \\
\hline \multicolumn{10}{|c|}{ Fuel cell mode } \\
\hline Option 2_1 & 6.3 & 30.0 & 0.61 & 8.1 & 3.7 & 1483 & 0.55 & 33.7 & 1.6 \\
\hline Option 2_2 & 8.0 & 192.7 & 0.62 & 4.8 & 20.4 & 907 & 0.78 & 40.5 & 0.6 \\
\hline \multicolumn{10}{|c|}{ Electrolysis mode } \\
\hline Option 2_1 & 6.4 & 39.6 & 0.72 & 5.3 & 9.0 & 2052 & 0.53 & 55.9 & 0.9 \\
\hline Option 2_2 & 2.0 & 223.4 & 0.56 & 4.2 & 2.8 & 3900 & 0.42 & 49.4 & 0.8 \\
\hline
\end{tabular}




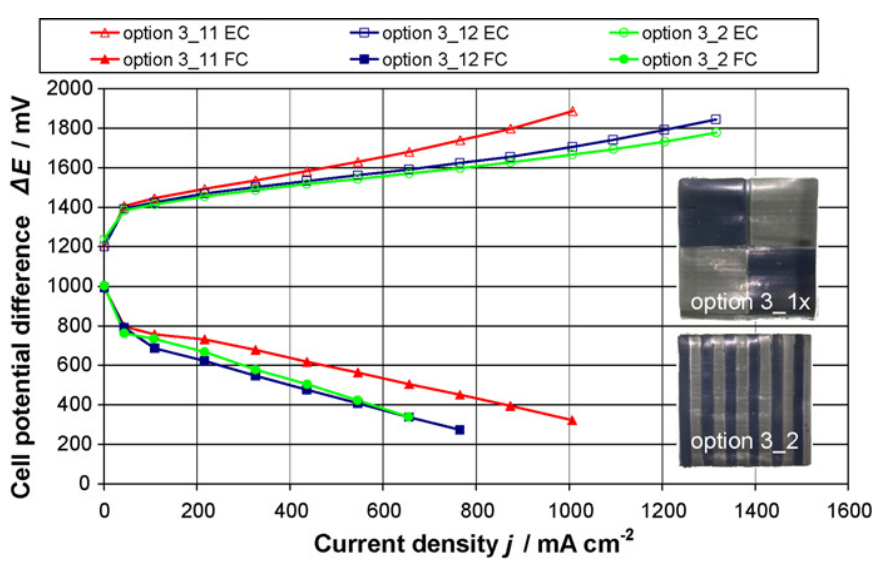

Fig. 6. $E(j)$ curves of Option 3 membrane electrode assemblies: Option 3_1 $\times$ with squares and Option 3_2 with stripes (black: Pt, grey: $\mathrm{IrO}_{2}$ ). (fuel cell mode: cell temperature $358 \mathrm{~K}$, ambient pressure, gases fully humidified, hydrogen flow $0.41 \mathrm{~min}^{-1}$, oxygen flow $0.41 \mathrm{~min}^{-1}$; electrolysis mode: cell temperature $368 \mathrm{~K}$, ambient pressure; no flows).

in the fuel cell and electrolysis modes provides the values given in Table 2. No large variation in element 3 in electrolysis mode was observed, but the charge transfer resistances (elements 1 and 4) show higher values for Option 2_1 as compared to Option 2_2.

The interpretation of the observed impedances in fuel cell mode is more complicated. The impedance of the MEA with the Pt layer next to the membrane (Option 2_1) is smaller only at low frequencies and is larger at high frequencies, compared to Option 2_2. The fit of the impedance spectra to the simple equivalent circuit in Fig. 5 indicates a significantly higher ohmic resistance for the Option 2_1 MEA, compared to the Option 2_2 MEA. The higher resistance occurs although the active layer (with Pt) is next to the membrane, and this arrangement shows superior performance in fuel cell operation (compare red triangles with blue squares in Fig. 3). The higher activity of the Option 2_1 MEA for the fuel cell mode is seen in the lower resistance of element 4 (Option 2_1 has the Pt layer next to the membrane). The higher ohmic resistance of Option 2_1 is therefore attributed to the electronic resistance of the outer $\mathrm{IrO}_{2}$ layer. In Option 2_2 MEA, the Pt layer is located next to the GDL, and the $\mathrm{IrO}_{2}$ layer is mainly ionic resistance for the fuel cell mode. The electronic conductivity of $\mathrm{IrO}_{2}$ is much lower $\left(<1.4 \times 10^{4} \Omega^{-1} \mathrm{~cm}^{-1}\right.$ [17]) than that of Pt $\left(9.66 \times 10^{4} \Omega^{-1} \mathrm{~cm}^{-1}\right)$, and the proton conductivity is similar because of the same content of Nafion in both layers. The higher ohmic resistance of the Option 2_1 MEA should be related to the differences in electronic conductivity. The poor ionic contact between the active layer (Pt outside) and the electrolyte of the Option 2_2 MEA results in a high cell impedance at low frequencies and in decreased fuel cell performance.

\subsection{Option 3}

In Option 3_1, the catalysts are distributed as square areas on the membrane. In Option 3_2, the different catalysts are distributed as stripes with smaller areas. The results of the Option 3 MEAs are presented in Fig. 6.

The Option 3_1 cells with the square segments show a strong sensitivity to the sequence of operation modes, which is not observed for the other options. The MEA Option 3_11 was used in fuel cell mode first and then in electrolysis mode. The order of operation for the Option 3_12 MEA was inverted, but otherwise the electrode configuration is equivalent. The $E(j)$ curves for both modes can be seen in Fig. 6. Superior fuel cell mode performance is observed for Option 3_11, whereas Option 3_12 exhibits superior performance in electrolysis mode. The distinct behaviour of

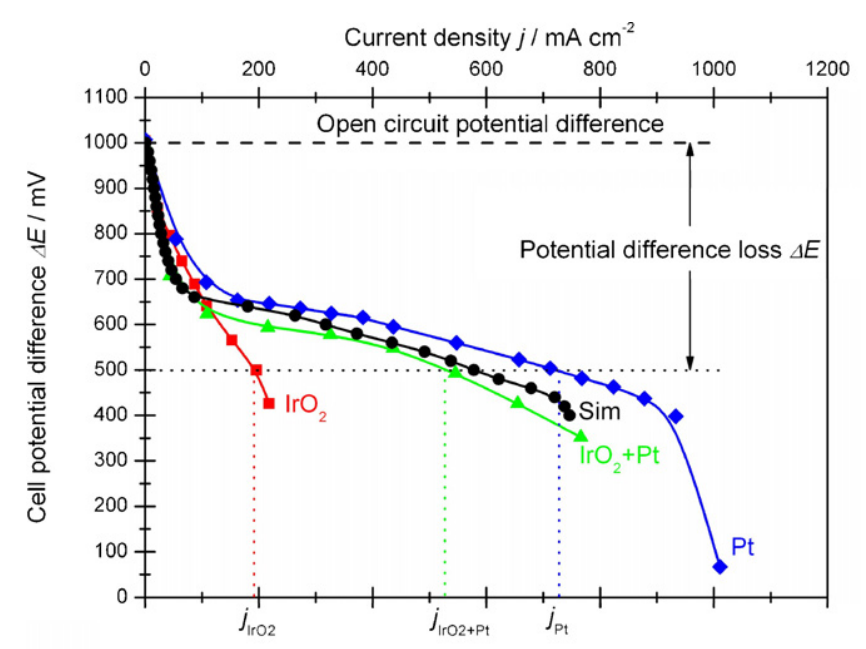

Fig. 7. $E(j)$ curves of Option 3_12 $\mathrm{MEA}\left(\mathrm{IrO}_{2}+\mathrm{Pt}\right)$, MEA with $\operatorname{IrO}_{2}$ catalyst $\left(\mathrm{IrO}_{2}\right), \mathrm{MEA}$ with Pt catalyst (Pt) and a simulation of the mixture of both (Sim).

the Option 3_1 cells may result from a change in the properties of the gas diffusion medium (e.g. the hydrophobicity of the layer) by the different operation conditions. During the start-up of the ordinary cells (prepared for unique operation as fuel cell), a strong loss of hydrophobicity is observed [18]. A support for this interpretation is that the Option 3 MEAs are similar, and the losses at the lower current densities (up to $100 \mathrm{~mA} \mathrm{~cm}^{-2}$ ) are small. The sequence of operation modes may not affect the intrinsic catalytic layer activity. However, the detailed processes in the electrode and gas diffusion media leading to the sequence dependence are not fully understood.

The Option 3_2 MEA shows negligible dependence on the working mode sequence and better overall performance and increased stability. By comparing Option 3_2 with specialised electrolysis and fuel cell MEAs (Fig. 8), the activity of the catalysts in different working modes can be predicted. In electrolysis mode, the performance of the segmented electrodes is slightly better than the specialised electrolysis electrode with the same amount of $\mathrm{IrO}_{2}$, which shows that $\mathrm{Pt}$ does not reduce the overall activity for oxygen evolution but increases it.

In fuel cell mode, the performance of the $E(j)$ curve is lower compared to a Pt fuel cell electrode, indicating an inhibiting effect of the segmented arrangement. For the Option 3 MEAs, the areas with Pt loading are expected to generate superior currents, and the areas with $\mathrm{IrO}_{2}$ loading are expected to exhibit low performance. However, the Pt areas are not expected to have a lower performance due to the presence of $\mathrm{IrO}_{2}$ areas. In the segmented electrodes, which are isolated from each other, imbalance due to contacting or the gas composition can lead to lateral equilibrating currents [19]. Here we have performance imbalance due to chemical differences in the electrode composition, and it is expected that the currents across the segments are present, which lead to an overall performance decrease for the MEA.

To obtain the cross current between the segments, the current density $j$ at the same potential loss $\triangle E$ (from the open cell potential difference) of the $E(j)$ curve of the $\mathrm{IrO}_{2} \mathrm{MEA}$ is subtracted from the $E(j)$ curve of the Pt MEA. This evaluation is given by Eq. (1). The factor $b$ is linked to the ratio of the segmented areas. In this case, the ratio is 0.5 , and the area is equal for both catalysts (Fig. 1 ). The subtraction according to Eq. (1) should result in the $E(j)$ curve of Option 3_1 MEA, and the curves are displayed in Fig. 7. The agreement between the simulated composite $E(j)$ curve and the measured curve is acceptable. This result demonstrates that the activity of heterogeneous electrode has a performance penalty. For electrodes with a homo- 


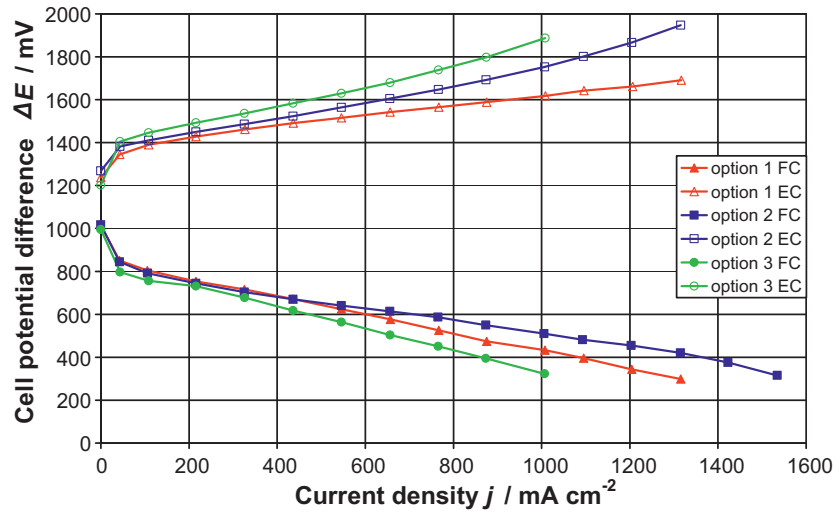

Fig. 8. $E(j)$ curves of best performing membrane electrode assemblies in fuel cell mode for the investigated electrode configurations. (Fuel cell mode: cell temperature $358 \mathrm{~K}$, ambient pressure, gases fully humidified, hydrogen flow $0.41 \mathrm{~min}^{-1}$, oxygen flow $0.41 \mathrm{~min}^{-1}$; electrolysis mode: cell temperature $368 \mathrm{~K}$, ambient pressure; no flows).

geneous chemical composition, heterogeneous area activity due to the operation conditions must be avoided [16,19-22].

$j(\Delta E)=b \times j(\Delta E)_{\mathrm{Pt}}-(1-b) \times j(\Delta E)_{\mathrm{IrO}_{2}}$

Fig. 8 shows the best performing $E(j)$ curves with relation to the fuel cell mode for the three investigated electrode composition options. Option 1, the state-of-the-art cell design, is chosen to be the reference system, and the other options are compared to this configuration.
The Option 3 MEA shows the lowest performance in both modes. The reduced active area, the resulting cross currents due to activity heterogeneity and a non-optimised gas diffusion medium are the reasons for this inferior performance. An optimisation of the cell, such as the use of segmented backings, could improve the performance of this electrode type.

The Option 2 MEA has advantages in fuel cell mode, while the Option 1 MEA shows better performance in electrolysis operation, especially at high current densities. However, if the performance is compared at approximately $700 \mathrm{mV}$ fuel cell operation at which the electrical efficiency is high, the performances of both cells are equivalent. Because the electrolysis performance of the first option is superior to the second option, the mixed catalysts structure is preferable for a technical application at this development stage. However, an improvement in the performance of multilayer electrodes is possible by applying a higher content of Nafion in the inner layer and possibly improving mass transport by introducing a pore former (to reduce the diffusion limitation) in the outer electrode layer.

In addition to the $E(j)$ curves, the impedance spectra provide information about the losses and are plotted in Fig. 9. The spectra for the electrolysis and fuel cell modes are distinct, and the two plots are displayed. The cell impedance and the ohmic resistance are much smaller in electrolysis mode as compared to the fuel cell mode. The higher water content and the increased ionic conductivity of the membrane are considered to be responsible for this result.

Comparing the different curves, the Option 3 MEA shows the highest cell impedance in fuel cell mode, which is in accordance
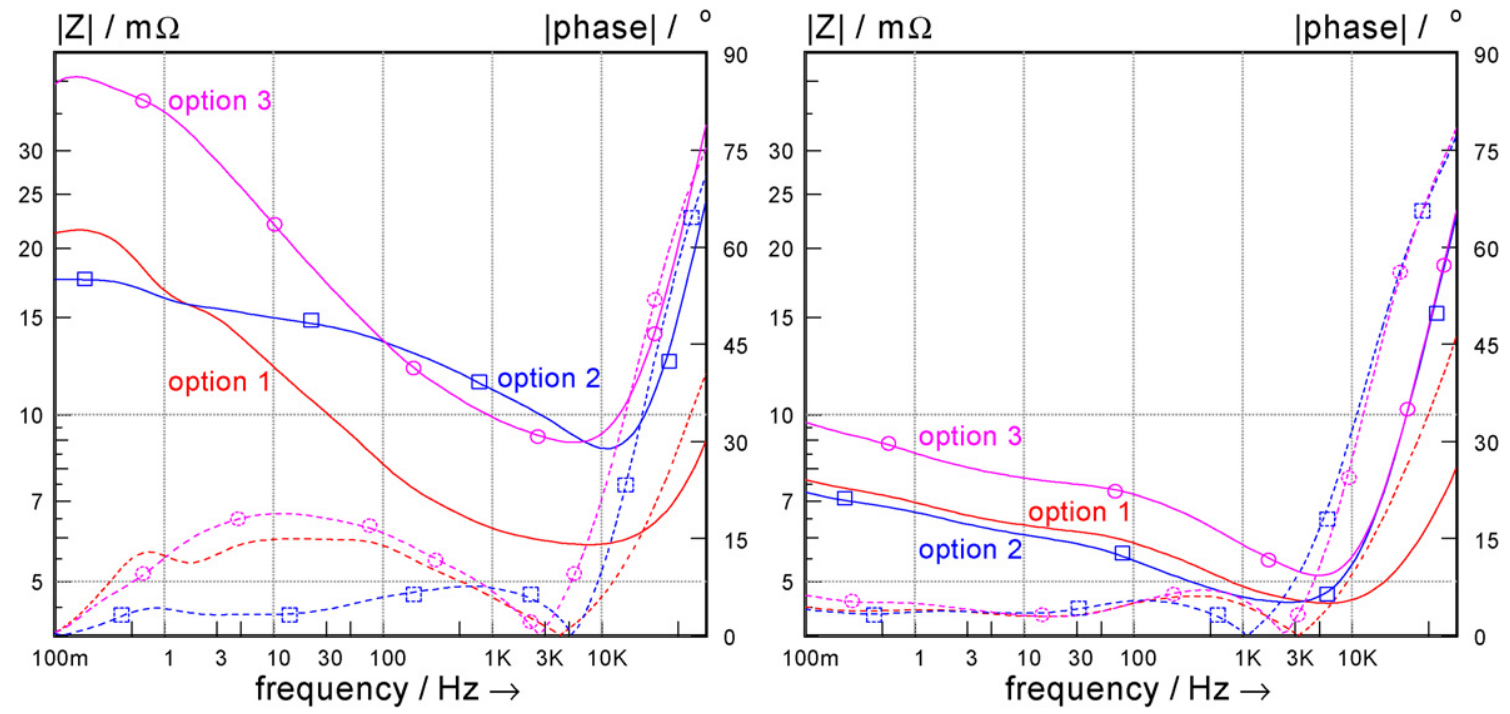

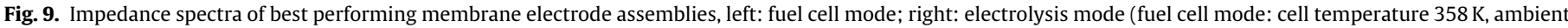
pressure, gases fully humidified, hydrogen flow $0.41 \mathrm{~min}^{-1}$, oxygen flow $0.41 \mathrm{~min}^{-1}$; electrolysis mode: cell temperature $368 \mathrm{~K}$, ambient pressure; no flows).

Table 3

Fit of impedance spectra of the best performance MEA options to equivalent circuit in Fig. 5 .

\begin{tabular}{|c|c|c|c|c|c|c|c|c|c|}
\hline \multirow{2}{*}{$\begin{array}{l}\text { Element } \\
\text { MEA }\end{array}$} & \multirow{2}{*}{$\begin{array}{l}1 \\
\mathrm{~m} \Omega\end{array}$} & \multicolumn{2}{|l|}{2} & \multirow{2}{*}{$\begin{array}{l}3 \\
\mathrm{~m} \Omega\end{array}$} & \multirow{2}{*}{$\begin{array}{l}4 \\
\mathrm{~m} \Omega\end{array}$} & \multicolumn{2}{|l|}{5} & \multirow{2}{*}{$\begin{array}{l}6 \\
\mathrm{nH}\end{array}$} & \multirow{2}{*}{$\begin{array}{l}\text { Error } \\
\%\end{array}$} \\
\hline & & $\mathrm{mF}$ & CPE exp. & & & $\mathrm{mF}$ & CPE exp. & & \\
\hline \multicolumn{10}{|c|}{ Fuel cell mode } \\
\hline Option 1 & 11.7 & 162.4 & 0.57 & 5.6 & 4.7 & 68260 & 1.03 & 12.4 & 1.8 \\
\hline Option 2 & 7.2 & 27.0 & 0.56 & 7.8 & 2.9 & 5207 & 0.68 & 35.5 & 1.4 \\
\hline Option 3 & 15.3 & 75.8 & 0.55 & 8.4 & 17.7 & 1293 & 0.81 & 55.2 & 1.3 \\
\hline \multicolumn{10}{|c|}{ Electrolysis mode } \\
\hline Option 1 & 1.9 & 163.1 & 0.68 & 4.3 & 2.1 & 6662 & 0.56 & 15.9 & 0.7 \\
\hline Option 2 & 1.7 & 319.7 & 0.67 & 4.4 & 1.9 & 6670 & 0.54 & 46.7 & 0.6 \\
\hline Option 3 & 2.8 & 80.9 & 0.70 & 4.7 & 4.2 & 4043 & 0.53 & 44.6 & 0.7 \\
\hline
\end{tabular}


with the observed performances in the $E(j)$ curves. The reason is the reduction of the actual active area by two and the cross currents. The Option 2 MEA has the smallest cell impedance but a higher ohmic resistance. This difference at high frequencies as compared to Option 1 is attributed to the much thicker electrode and the reduced electrical conductivity of the pure $\mathrm{IrO}_{2}$ layer.

In electrolysis mode, the Option 1 MEA has the smallest impedance and the best performance. Unexpectedly, the Option 2 MEA shows the largest impedance at low frequency, which may reflect the importance of diffusion limitations by the multilayer configuration in this frequency range. The multilayer structure may be responsible for the higher water transport resistance to the electrode. This interpretation is supported by the values obtained from the equivalent circuit fit in Table 3. The charge transfer resistances of the Option 2 MEA are not significantly different compared to Option 1. For Option 3 MEAs, the charge resistances are higher by a factor of about 2 in electrolysis mode and a factor of 2 to 3 in fuel cell mode.

\section{Conclusions}

In this work, different oxygen electrode configurations for the operation in a unitised reversible fuel cell were tested. Different combinations for structuring bifunctional electrodes based on the primary catalysts are compared. The combinations were produced from a mixture of catalysts, layered structures with the two different catalyst layers and segmented areas with single catalysts. The mixture of both catalysts ( $\mathrm{Pt}$ and $\mathrm{IrO}_{2}$ ) performs best for the present stage of electrode development. The multilayer electrodes yield promising results with the potential for optimisation by improving the electronic conductivities and mass transport properties of the specific layers. The interfacial contact to the membrane is important for performance and determines the ohmic resistance of the cell. Also, chemical segmentation leads to performance imbalances in fuel cell mode, which are partially compensated by lateral currents in the electrode. The imbalances lead to an additional performance penalty for this arrangement. From the impedance analysis, the general performance trends of the different structuring options are identified.

For all of the MEAs, only short-term stability was achieved. One challenge for further development is to increase the lifetime. Optimisation of the carbon gas diffusion medium is necessary. Different materials for gas diffusion should be also considered.

\section{References}

[1] F. Barbir, T. Molter, L. Dalton, Int. J. Hydrogen Energy 30 (2005) 351.

[2] H. Ito, T. Maeda, A. Kato, T. Yoshida, O. Ulleberg, ECS Trans. 25 (2009) 1979.

[3] H.-Y. Jung, P. Ganesan, B. Popov, ECS Trans. 25 (2009) 1261.

[4] B. Kneidel, Auslegung und Simulation von hochfliegenden, dauerhaft stationierbaren Solardrohnen, PhD Thesis, Technische Universitaet Muenchen, Munich, 2000.

[5] W. Smith, J. Power Sources 86 (2000) 74.

[6] K.A. Burke, Unitized Regenerative Fuel Cell System Development, NASA/TM2003-212739, 2003.

[7] T. Ioroi, N. Kitazawa, K. Yasuda, Y. Yamamoto, H. Takenaka, J. Electrochem. Soc. 147 (2000) 2018.

[8] K. Ledjeff, F. Mahlendorf, V. Peinecke, A. Heinzel, Electrochim. Acta 40 (1995) 315.

[9] H. Liu, B. Yi, M. Hou, J. Wu, Z. Hou, H. Zhang, Electrochem. Solid State Lett. 7 (2004) A56.

[10] P. Millet, R. Durand, M. Pineri, Int. J. Hydrogen Energy 15 (1990) 245.

[11] E. Rasten, G. Hagen, R. Tunold, Electrochim. Acta 48 (2003) 3945.

[12] S. Song, H. Zhang, X. Ma, Z.-G. Shao, Y. Zang, B. Yi, Electrochem. Commun. 8 (2006) 399.

[13] R.A. van Santen, P.W.N.M. van Leeuwen, Catalysis: An Integrated Approach, Elsevier, Amsterdam, 1999.

[14] H.Wendt, Electrochemical Hydrogen Technologies Electrochemical Production and Combustion of Hydrogen, Elsevier, Amsterdam, 1990.

[15] U. Wittstadt, E. Wagner, T. Jungmann, J. Power Sources 145 (2005) 555.

[16] E. Gülzow, M. Schulze, N. Wagner, T. Kaz, R. Reissner, G. Steinhilber, A. Schneider, J. Power Sources 86 (2000) 352.

[17] P.C. Liao, Y.S. Huang, K.K. Tiong, J. Alloys Compd. 317-318 (2001) 98.

[18] R.P. Ramasamy, E.C. Kumbur, M.M. Mench, W. Liu, D. Moore, M. Murthy, Int. J. Hydrogen Energy 33 (2008) 3351.

[19] P. Metzger, Charakterisierung von oxidkeramischen FestelektrolytBrennstoffzellen durch ortsaufgelöste Messungen, PhD Thesis, University of Stuttgart, Stuttgart, 2010.

[20] S.J.C. Cleghorn, C.R. Derouin, M.S. Wilson, S. Gottesfeld, J. Appl. Electrochem. 28 (1998) 663.

[21] M. Schulze, E. Gülzow, St. Schönbauer, T. Knöri, R. Reissner, J. Power Sources 173 (2007) 19.

[22] J. Stumper, S.A. Campbell, D.P. Wilkinson, M.C. Johnson, M. Davis, Electrochim. Acta 43 (1998) 3773. 